\title{
EGGPLANT GROWTH AS AFFECTED BY BOVINE MANURE AND MAGNESIUM THERMOPHOSPHATE RATES
} \author{
Pereira de Souza ${ }^{2}$ \\ ${ }^{1}$ Embrapa Amazônia Ocidental, C.P. 319 - 69010-970 - Manaus, AM - Brasil. \\ ${ }^{2}$ UFPB - Centro de Ciências Agrárias, C.P. 02 - 58397-000 - Areia, PB - Brasil. \\ *Corresponding author <marinice.cardoso@cpaa.embrapa.br>
}

Marinice Oliveira Cardoso ${ }^{1 *}$; Walter Esfrain Pereira ${ }^{2}$; Ademar Pereira de Oliveira ${ }^{2}$; Adailson

ABSTRACT: Plant growth is influenced by nutrient availability. The objective of this research was to study, under greenhouse conditions, eggplant growth as affected by rates of bovine manure and magnesium thermophosphate $\left(\mathrm{g} \mathrm{kg}^{-1}\right.$ and $\mathrm{mg} \mathrm{kg}^{-1}$, respectively), according to a "Box central composite" matrix: 4.15-259; 4.15-1509; 24.15-259; 24.15-1509; 0.0-884; 28.3-884; 14.15-0,0; 14.15 $1768 ; 14.15-884$.-Potassium sulfate $\left(170 \mathrm{mg} \mathrm{kg}^{-1}\right)$ and $200 \mathrm{~mL}$ per pot of cow urine solution were applied four times, but the concentration of the last two applications $\left(200 \mathrm{~mL} / \mathrm{H}_{2} \mathrm{O} \mathrm{L}\right)$ was twice of that of the first two. Additional treatments: magnesium thermophosphate without cow urine and triple superphosphate with urea, both with nutrient levels equivalent to the bovine manure, $\mathrm{P}_{2} \mathrm{O}_{5}$ and potassium sulfate to the combination 14.15-884. The experimental design consisted of randomized blocks with four replicates. Leaf area (LA) and LA ratio increased as quadratic functions with manure rates, with negative interaction for thermophosphate. Leaf dry matter mass (DMM) had an increasing quadratic function with rates for both fertilizers. The higher combined rates of both fertilizers resulted in the smallest specific leaf area, but also the highest values of shoot and root DMM, total DMM and, with positive interaction in relation to root shoot dry matter ratio. The relative growth rate in stem height, and also in diameter, increased with manure, according to quadratic and linear functions, respectively. The cow urine effect was, in general, lower than that of urea. The plant's overall growth was more influenced by manure. Root DMM and shoot DMM were greater with high $\mathrm{K}$ and $\mathrm{P}$.

Key words: Solanum melongena, organic fertilization, phosphorus, cow urine

\section{CRESCIMENTO DA BERINJELA EM FUNÇÃO DE DOSES DE ESTERCO BOVINO E DE TERMOFOSFATO MAGNESIANO}

\begin{abstract}
RESUMO: O crescimento em plantas é influenciado pela disponibilidade de nutrientes. O objetivo deste trabalho foi estudar, em abrigo telado, o crescimento da berinjela em função de doses de esterco bovino e termofosfato magnesiano $\left(\mathrm{g} \mathrm{kg}^{-1}-\mathrm{mg} \mathrm{kg}^{-1}\right.$, respectivamente), conforme a matriz "composto central de Box": 4, 15-259; 4,15-1509; 24,15-259; 24,15-1509; 0,0-884; 28,3-884; 14, 15-0,0; $14,15-1768 ; \underline{14,15-884}$. Acrescentaram-se sulfato de potássio $\left(170 \mathrm{mg} \mathrm{kg}^{-1}\right)$ e quatro parcelas de 50 $\mathrm{mL}$ por vaso de solução de urina de vaca, as duas últimas possuindo concentração de $200 \mathrm{~mL} \mathrm{~L}^{-1}$ de $\mathrm{H}_{2} \mathrm{O}$, o dobro da inicial. Tratamentos adicionais: termofosfato magnesiano sem urina de vaca e superfosfato triplo com uréia, iguais em esterco, $\mathrm{P}_{2} \mathrm{O}_{5}$ e sulfato de potássio, à combinação 14,15-884. $\mathrm{O}$ delineamento experimental foi em blocos casualizados com quatro repetições. A área foliar (AF) e a razão de AF aumentaram, quadraticamente, com as doses de esterco, porém, a interação com o termofosfato foi negativa. A massa de matéria seca (MMS) de folhas incrementou, quadraticamente, com as doses dos dois insumos. Na combinação das maiores doses de ambos ocorreram a menor AF específica e os maiores valores da MMS da parte aérea, MMS de raízes, MMS total e, por interação positiva, da relação raiz parte aérea. A taxa de crescimento relativo em altura caulinar, e em diâmetro, aumentaram, quadrática e linearmente, somente com o esterco, respectivamente. A urina de vaca teve efeito, em geral, inferior ao da uréia. O crescimento geral da planta foi mais responsivo ao esterco. A MMSR e a MMSPA foram maiores com elevada disponibilidade de $\mathrm{K}$ e $\mathrm{P}$ no substrato.

Palavras-chave: Solanum melongena, adubação orgânica, fósforo, urina de vaca
\end{abstract}




\section{INTRODUCTION}

The eggplant has been of increased importance among vegetables due to the great popularization of its nutraceutic value (Cardoso, 2005). This vegetable is well adaptated to the tropical climate, however, its growth is quite influenced by nitrogen and phosphorus availability (Swiader \& Morse, 1982; Filgueira, 2003). In nutrient solution, nitrogen absence affects the growth of new leaves and stems, and in phosphorus absence fruit formation does not occur (Haag \& Homa, 1968). Nitrogen is essential for plant growth because it is part of the proteins and nucleic acids. These are basic components of plant protoplasm and chlorophyll, both indispensable for photosynthesis (Taiz \& Zeiger, 2004). Likewise, phosphorus is essential for plants as an element of plant structure, as well as a component of energy compounds, e.g. adenosine triphosphate-ATP (Malavolta, 1980). The eggplant presents a high yield potential in organic production systems, which are worldwide in crescent expansion. In this way, nitrogen is supplied only by organic sources, and phosphorus by low solubility phosphates, such as magnesium thermophosphate (FAO, 1999). Cow urine is also used as a nitrogen source in organic systems (Boddey et al., 2000). However, there is little information about the eggplant performance when these nutrient sources are combined. In general, organic matter has positive effects on its performance. Magnesium thermophosphate may be quite effective for short cycle plants due its high solubility in citric acid (Souza \& Yasuda, 2003). Growth analysis allows the study of agronomic practices effects on plants, like nutrient supply (Pereira \& Machado, 1987). When made under a protected environment, it is useful to obtain preliminary information to subsidize further studies to be carried out under field conditions. The objective of this study was to evaluate the effect of bovine manure and magnesium thermophosphate applications, when associated with cow urine, on eggplant growth.

\section{MATERIAL AND METHODS}

The experiment was carried in a greenhouse, in Areia ( $6^{\circ} 58^{\prime} \mathrm{S} ; 35^{\circ} 42^{\prime} \mathrm{W}, 574.62 \mathrm{~m}$, above sea level), State of Paraíba, Brazil. A random block design was used, with four replicates, with plots consisting of a pot of volume $15 \mathrm{dm}^{3}$, with substrate containing a single eggplant of the cultivar Ciça. The substrate was the superficial horizon of a sandy soil $\left(\mathrm{pH}\right.$ in $\mathrm{H}_{2} \mathrm{O}, 1: 2.5$ $=5.7$; organic matter, $\mathrm{P}$ and $\mathrm{K}^{+}=19.3 ; 3.7 ; 48.3 \mathrm{mg}$ $\mathrm{dm}^{3}$, respectively; $\mathrm{Ca}^{+2}, \mathrm{Mg}^{+2},\left(\mathrm{H}^{+}+\mathrm{Al}^{+3}\right)$ and $\mathrm{Al}^{+3}=27$; $10 ; 61.9 ; 0.0 \mathrm{mmol}_{\mathrm{c}} \mathrm{dm}^{-3}$, respectively), sieved through a $4 \mathrm{~mm}$ sieve. Treatments were rates of bovine manure and magnesium thermophosphate $\left(\mathrm{g} \mathrm{kg}^{-1}\right.$ and $\mathrm{mg}$ $\mathrm{kg}^{-1}: 4.15-259 ; 4.15-1509 ; 24.15-259 ; 24.15-1509$; $0.0-884 ; 28.3-884 ; 14.15-0.0 ; 14.15-1768 ; 14.15-884$, respectively), combined according to predetermined levels of the "Box central composition" matrix (Bortoluzzi \& Alvarez V., 1997). Potassium sulfate $\left(170 \mathrm{mg} \mathrm{kg}^{-1}\right)$ and cow urine were also applied. To treatments of magnesium thermophosphate without cow urine and triple superphosphate with urea, were supplemented equivalently with, bovine manure and $\mathrm{P}_{2} \mathrm{O}_{5}$ rates in relation to the medium interval point rate (14.15-884), with the same potassium addition as all others.

Bovine manure had the following composition: N, P, K, S, Ca, Mg (10.3; 3.6; 22.3; 6.7; 2.5; $10.8 \mathrm{~g}$ $\mathrm{kg}^{-1}$, respectively); B, Cu, Fe, Mn, Zn (3; 15; 8964; $278.5 ; 64.3 \mathrm{mg} \mathrm{kg}^{-1}$, respectively); and $\mathrm{Na}=7553.3$ $\mathrm{mg} \mathrm{kg}{ }^{-1}$. Cow urine analysis had $\mathrm{N}, \mathrm{P}, \mathrm{K}, \mathrm{Ca}, \mathrm{Mg}, \mathrm{S}$ (3; 0.0016; 61.33;0.02;0.28; $0.49 \mathrm{~g} \mathrm{~L}^{-1}$, respectively); $\mathrm{B}, \mathrm{Cu}, \mathrm{Fe}, \mathrm{Mn}$ and $\mathrm{Zn}(38.8 ; 0.07 ; 0.95 ; 0.12 ; 0.17$ $\mathrm{mg} \mathrm{L}^{-1}$, respectively); and $\mathrm{Na}=1031.3 \mathrm{mg} \mathrm{L}^{-1}$. Magnesium thermophosphate of the Yoorin Master type presented: total $\mathrm{P}_{2} \mathrm{O}_{5}=17.5 \%$; soluble $\mathrm{P}_{2} \mathrm{O}_{5}$ in $2 \%$ citric acid $=16 \% ; \mathrm{Ca}=20 \% ; \mathrm{Mg}=7 \% ; \mathrm{B}=0.10 \% ; \mathrm{Cu}$ $=0.05 \% ; \mathrm{Mo}=0.006 \% ; \mathrm{Mn}=0.12 \% ;$ and $\mathrm{Zn}=0.55 \%$.

The pots were filled with substrate and fertilizers one week before transplant. Irrigation was carried out to near to field capacity and was maintained during the trial. Seedlings produced in polystyrene trays were transplanted with four to five definitive leaves. After planting, daily irrigations varied from 250 $\mathrm{mL}$, at the beginning, to $500 \mathrm{~mL}$, at the end of the cycle. At 15, 30, 45 and 60 days after planting, 50 $\mathrm{mL}$ of cow urine solution were applied per pot diluted in the irrigation water, but on the last two occasions the solution was doubled to $100 \mathrm{~mL}$ (Gadelha, 2001). In the urea treatment, $0.5 \mathrm{~g}$ per pot were applied with the irrigation water. The tutored new plants sprouts originating beneath the first bifurcation were eliminated in two ocassions. The rare spontaneous seedlings were also eliminated.

Twenty (t1) and eighty days (t2) after transplant stem height (L, in $\mathrm{mm}$ ) was measured from the base of stem to the last leaf insert of the highest stem, in order to calculate the relative growth rate of stem height [RGRSH, cm $/ \mathrm{cm}$ day $^{-1}=\log _{\mathrm{n}} \mathrm{L} 2-\log _{\mathrm{n}} \mathrm{L} 1 /(\mathrm{t} 2$ t1]. Stem diameter $(\mathrm{C}, \mathrm{mm})$, was measured at the first definitive leaf insert area and to calculate the relative growth rate of stem diameter [RGRSD, $\mathrm{cm} / \mathrm{cm}$ day $^{-1}$ $=\log _{\mathrm{n}} \mathrm{C} 2-\log _{\mathrm{n}} \mathrm{C} 1 /(\mathrm{t} 2-\mathrm{t} 1]$, according to Hunt (1990).

When the trial ended (t2), two leaf blades were taken from the upper, medium and lower thirds of the plant, in order to remove $36 \mathrm{~cm}^{2}$ foliar square areas. 
These squares, together with the rest of the intact leaf blades were dried in paper bags in a forced air drier $\left(65^{\circ} \mathrm{C}\right)$ until reaching constant weight. Square dry matter mass (sqdmm), total square area (sqta) and leaf dry matter mass (LDMM) were used to calculate the leaf area (Pereira \& Machado, 1987; Benincasa, 1988): $\mathrm{LA}=$ sqta $\times \mathrm{LDMM} / \mathrm{sqdmm}$. The dry matter of abscissed leaves during the cycle, was included in LDMM. Specific leaf area (SLA) was obtained the dividing LA by LDMM.

After removing the leaves, the stem (cut close to soil surface, stalks, and other remaining structures were also dried to constant weight, as well as fruits separated from the peduncles. Fruit production was observed only in seven parcels (one fruit per parcel). The dry matter masses of the stem, petioles (including those that fell off during the cycle), flowers and peduncles, in addition to LDMM, constituted the shoot dry matter mass (SDMM). Total dry matter mass (TDMM) was obtained from the sum of SDMM with fruit dry matter mass and root dry matter mass (RDMM). Leaf area ratio (LAR) was estimated from the ratio LA / TDMM. Larger roots were manually separated from the substrate, while the separation of the other roots was made through successive separation in sieves of $10 \mathrm{~mm}, 4 \mathrm{~mm}$ and $2 \mathrm{~mm}$ mesh, with adhered particles removed through washing in a of with $0.4 \mathrm{~mm}$ mesh (Hallmark \& Barber, 1984) and tweezers. After air drying $\left(65^{\circ} \mathrm{C}\right)$ to constant weight, root dry matter mass (RDMM) was determined. Rootshoot dry matter ratio (RSDMR) was calculated dividing root dry matter mass (RDMM) by shoot dry matter mass (SDMM). At the end substrate samples of the pots were removed for chemical characterization according to Ferreira et al. (1990).

Data analysis was made with the aid of the SAEG 5.0 software (Ribeiro Júnior, 2001). Response curves were estimated in the case of isolated factor significance, and response surfaces were used when significance occurred for both factors or for the interaction. Significance levels to accept the isolated effect within of the model were chosen up to $10 \%$ (Alvarez V., 1991). For each variable, the rate that provided maximum or minimum values was obtained by setting the first derivative equal to zero, in the case of the simple regression equation. Partial derivatives in relation to each factor were used for polynomial equation regression. In the contrast analysis the $\mathrm{F}$ test was used because it is decisive in the case of two averages (Gomes, 1985). The Bonferroni test was also applied due to its non-orthogonality (Gill, 1990). Principal components analysis was used and the response of these components to the experimental factors was studied (Caradus et al., 1993). The correlation matrix autovalue $(\lambda)$ was considered up to 0.7 , according to the Jolliffe criterion (Jackson, 1991). The canonical correlation technique was also used (Rencher, 1992). These multivariate analysis techniques were applied only to the treatments involved in the regression.

\section{RESULTS AND DISCUSSION}

\section{Leaf area, leaf dry matter mass and specific leaf area}

LA increased in a quadratic way with bovine manure application rates, reaching $5421 \mathrm{~cm}^{2} /$ plant for the highest rate $\left(28.3 \mathrm{~g} \mathrm{~kg}^{-1}\right)$, in the absence of magnesium thermophosphate, due to the negative interaction among the input rates (Figure 1). The positive effect of bovine manure is in agreement with Silva et al. (1999), who an LA area increase for pumpkin as a function of organic composition rates. On the other hand, the decrease of LA starting from the maximum rate of bovine manure $\left(31 \mathrm{~g} \mathrm{~kg}^{-1}\right)$ possibly occurred because of the nutrient deviation to other components, in detriment of leaf expansion. This explanation is supported by the fact that shoot dry matter mass increased lineally with organic fertilizer doses, which demonstrates great demand. The negative interaction was probably due to the competitive effect of other nutrients supplied by the magnesium thermophosphate, or even to their corrective effects in modifying $\mathrm{pH}$, influencing the organic matter mineralization and nutrient absorption.

LDMM increased, in a quadratic way, reaching its highest value $\left(22.01 \mathrm{~g} \mathrm{plant}^{-1}\right)$ with the combination of $28.3 \mathrm{~g} \mathrm{~kg}^{-1}$ and $1153 \mathrm{mg} \mathrm{kg}^{-1}$ of bovine manure and magnesium thermophosphate rates, respectively (Figure 2). However, the linear increment promoted by bovine manure was higher than that of the

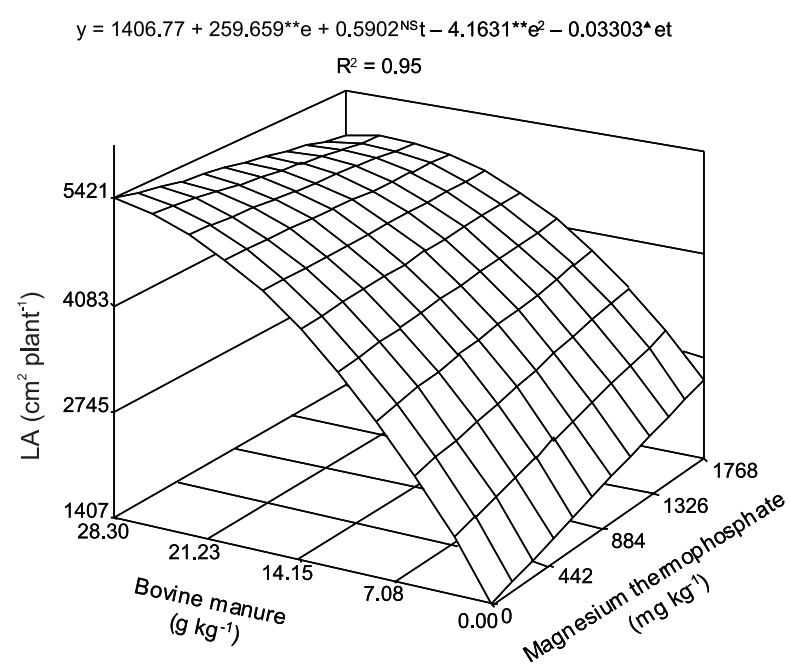

Figure 1 - Eggplant leaf area (LA) as a function of bovine manure and magnesium thermophosphate rates. 


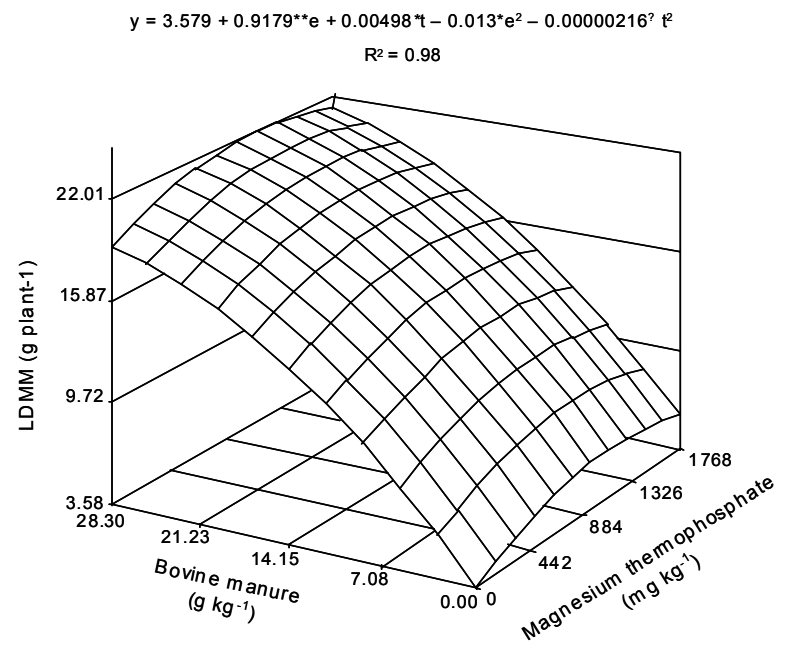

Figure 2 - Eggplant leaf dry matter mass (LDMM) as a function of bovine manure and magnesium thermophosphate rates.

magnesium thermophosphate, probably because it is a good nitrogen source. Organic fertilizers affect low molecular weight organic fraction absorption, which act both as growth regulators and by increasing cell membrane permeability, favoring absorption (Mendonça \& Loures, 1995). Nitrogen is the nutrient demanded in largest amounts by plants (Taiz \& Zeiger, 2004). To produce the same amount of dry matter, tomatoes leaf required more nitrogen than the stem (Ronchi et al., 2001). In other species, leaf dry matter increase has been observed when the phosphorus supply is increased (Abreu et al., 2002; Rodrigues et al., 2004), which could explain the magnesium thermophosphate effect, because it is an essential component of all organisms. Therefore, its deficit causes biomass decrease (Mapeli et al., 2005).

SLA decreased linearly with the increase of bovine manure and magnesium thermophosphate rates, reaching $231.73 \mathrm{~cm}^{2} \mathrm{~g}^{-1}$ at the maximum rates combination (Figure 3). Therefore, both inputs reduced the ratio between the assimilative surface and the dry mass of the leaf. This occurs due to a decrease in leaf area expansion and increase in the mechanical and conductive tissues, which result in a greater. As eggplant has continuous growth, the leaves may not expand at the same rates while growth is occuring, and this, according to Scott \& Batchelor (1979), promotes decreased SLA. Thus, if the mass is considered as directly related to volume, SLA indicates inverse leaf thickness (Fontes et al., 2005).

\section{Shoot dry matter mass, root dry matter mass and total dry matter mass}

In terms of SDMM, bovine manure was superior to magnesium thermophosphate in promoting a

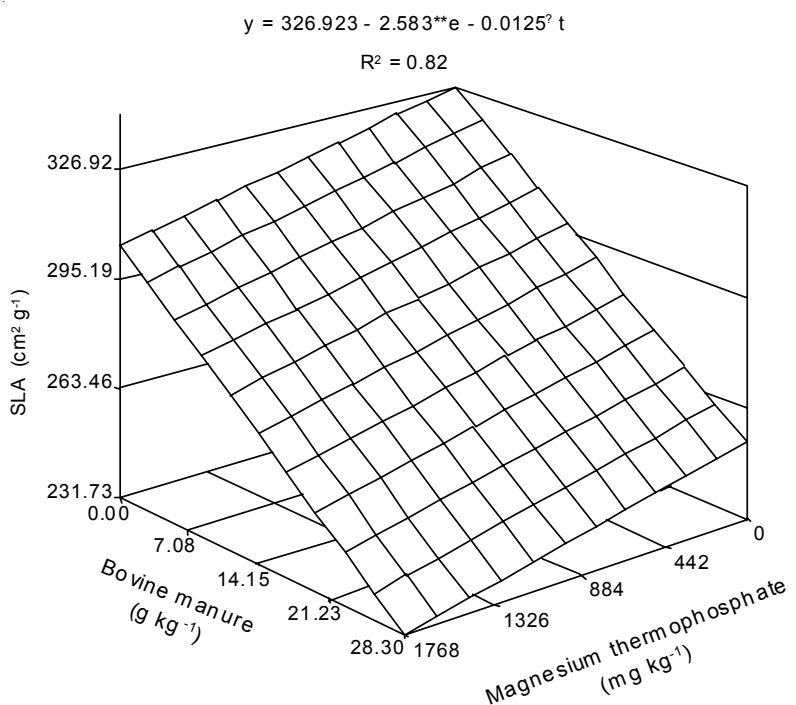

Figure 3 - Eggplant specific leaf area (SLA) as a function of bovine manure and magnesium thermophosphate rates.

linear increment (1.208 g) for each added unit of input (Figure 4). This is certainly due to its well-known beneficial role on soil properties and plant mineral nutrition (Kiehl, 1985). The increase of SDMM up to 50.28 g plant $^{-1}$ with the combination of the largest applied rate might have occurred, more specifically, because of the nitrogen and phosphorus of bovine manure and magnesium thermophosphate. Nitrogen is the main component of proteins and is responsible for linked attributes of plant load (Taiz \& Zeiger, 2004), and therefore its ack affects new leaf and stem growth (Haag \& Homa, 1968). Phosphorus deficiency is also very harmful for plants shoot growth (Grant et al., 2001). For tomato, SDMM increased with nitrogen rates (Ferreira et al., 2003) and when phosphorus concentrations were increased in soil solution (Fontes \& Wilcox, 1984). Furthermore, the dry mass of chamomile inflorescences was higher when nitrogen and phosphorus were supplied together, but not when supplied separately (Mapeli et al., 2005).

RDMM reached its highest value (16.74 g plant $^{-1}$ ) with the combination of the highest rates of bovine manure and magnesium thermophosphate (Figure 5). Root growth might have been limited by pot volume, because eggplant roots can reach $1 \mathrm{~m}$ in depth (Ribeiro et al., 1998) under field conditions. Increase in root growth due to organic fertilizers has been related to nutrient supply and to increased absorption (Mendonça \& Loures, 1995), and also to physical and hydrophilic substrate improvement, among other factors (Bayer \& Mielniczuk, 1999). On the other hand, nitrogen, which is present in bovine manure, has an outstanding effect on root growth (Marschner, 1995) because when this nutrient increases the leaf area, it 


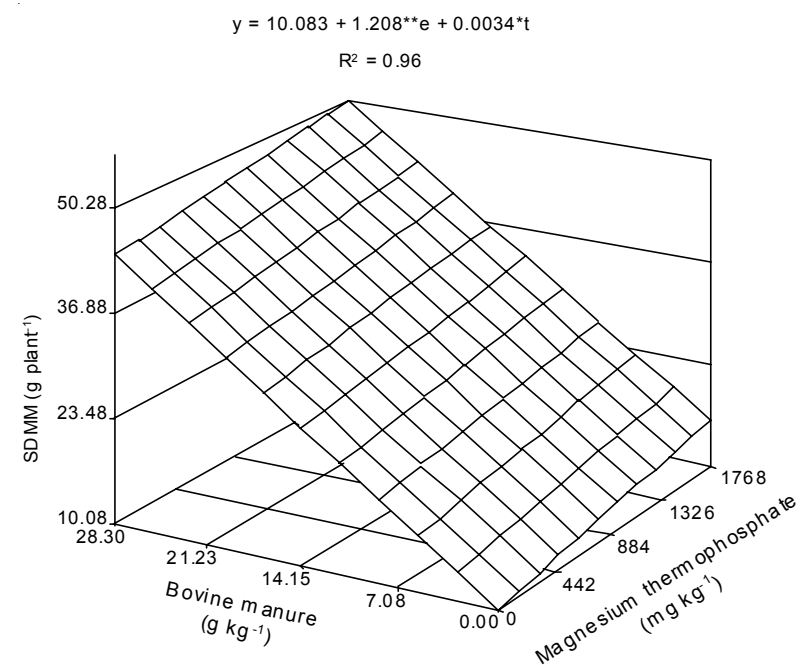

Figure 4 - Eggplant shoot dry matter mass (SDMM) as a function of bovine manure and magnesium thermophosphate rates.

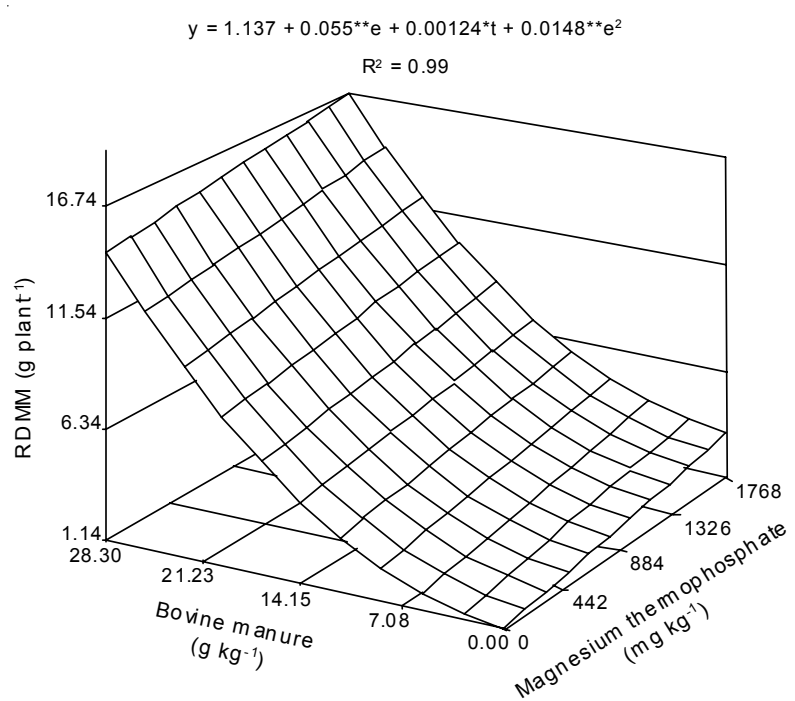

Figure 5 - Eggplant root dry matter mass (RDMM) as a function of bovine manure and magnesium thermophosphate rates.

promotes a photosynthesis increase, which is favorable to root growth. Phosphorus, which is present in magnesium thermophosphate, shows an indirect and a less accentuated effect (Yamada, 2002). This is in agreement with its discreet linear increment. However, very high phosphorus contents in the soil reduced tomato root dry matter mass (Fontes \& Wilcox, 1984). Nevertheless, for eggplant, no negative effect of magnesium thermophosphate was observed.

TDMM was adjusted to a quadratic root model as a function of bovine manure and magnesium thermophosphate rates (Figure 6), reaching $66.53 \mathrm{~g}$ plant $^{-1}$ with the combination of the highest rates. This summarizes the behavior of SDMM and RDMM, which increased with these fertilizers rates.

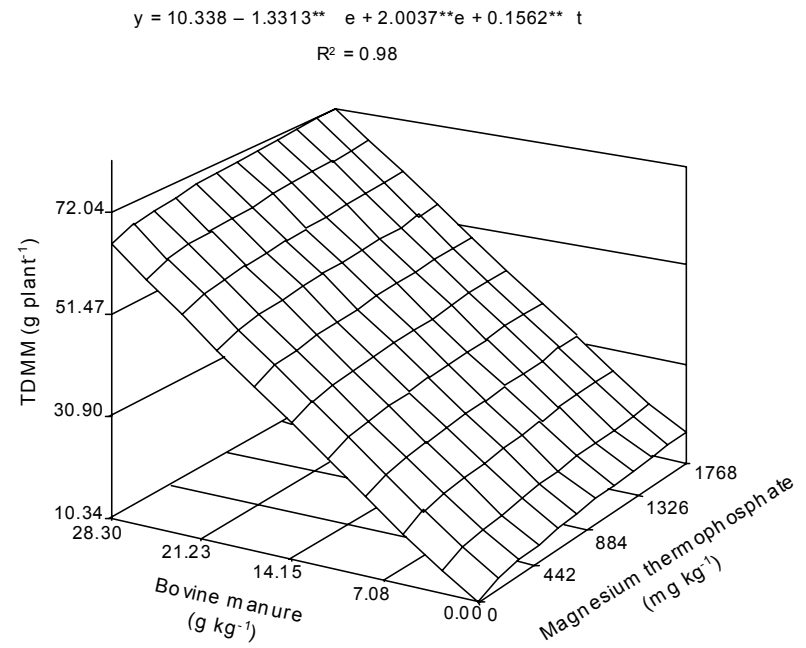

Figure 6 - Eggplant total dry matter mass (TDMM) as a function of bovine manure and magnesium thermophosphate rates.

\section{Leaf area ratio and root shoot dry matter ratio}

The interaction between bovine manure and magnesium thermophosphate rates was negative in relation to LAR following quadratic and linear regression models, respectively (Figure 7). The maximum LAR value $\left(127 \mathrm{~cm}^{2} \mathrm{~g}^{-1}\right)$ occurred with $8.4 \mathrm{~g} \mathrm{~kg}^{-1}$ of bovine manure and zero magnesium thermophosphate, while the minimum value at the highest rates of these inputs $\left(28.3 \mathrm{~g} \mathrm{~kg}^{-1}\right.$ and $1768 \mathrm{mg} \mathrm{kg}^{-1}$, respectively). Decreasing LAR indicates that there is a decrease in photoassimilates assigned to leaves (Brighenti et al., 1993). It is possible that, as a consequence, the relative growth rate decreases (Fontes et al., 2005). LAR may also decrease as a result of self-shading, which promotes leaf area decrease (Benincasa, 1988). Eggplant vegetative growth, with stem bifurcation, may be responsible for this since the leaves from the secondary stems had smaller areas, which suggests use of the photoassimilates preferentially for stem formation. This also suggests that the available nitrogen was insufficient for both parts.

RSDMR decreased quadratically with bovine manure rates and linearly with magnesium thermophosphate rates (Figure 8). The, positive interaction indicates that together they increased this relation, which is in agreement with Marschner (1995). The minimum RSDMR $\left(0.18 \mathrm{~g} \mathrm{~g}^{-1}\right)$ were was reached with $5.8 \mathrm{~g} \mathrm{~kg}^{-1}$ of bovine manure, together with 934.1 $\mathrm{mg} \mathrm{kg}{ }^{-1}$ of magnesium thermophosphate, but attained to $0.398 \mathrm{~g} \mathrm{~g}^{-1}$ with the maximum rates of both inputs. A very intense increment of up to $5.8 \mathrm{~g} \mathrm{~kg}^{-1}$ of bovine manure agrees with Yamada (2002), who stated that roots proliferate in an environment containing or- 


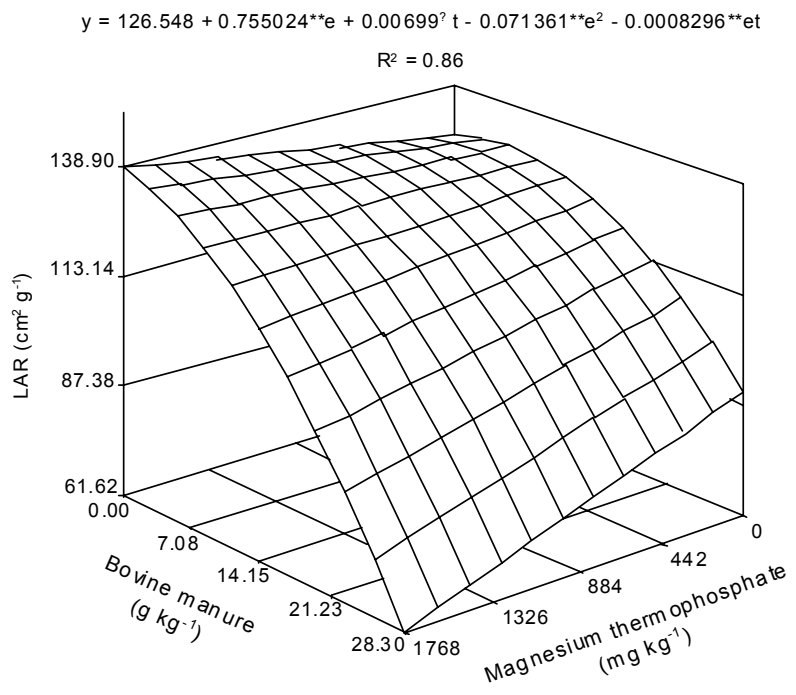

Figure 7 - Eggplant leaf area ratio (LAR) as a function of bovine manure and magnesium thermophosphate rates.

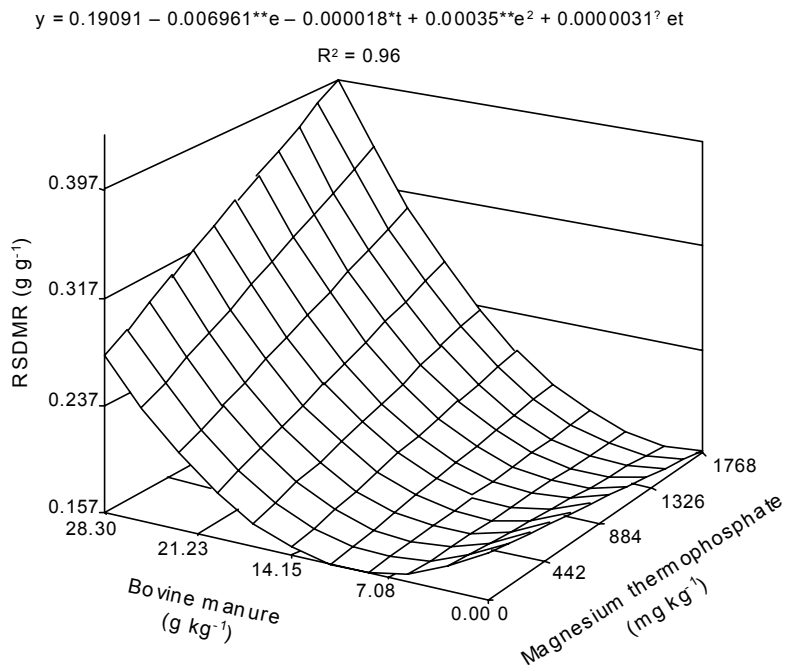

Figure 8 - Eggplant root shoot dry matter ratio (RSDMR) as a function of bovine manure and magnesium thermophosphate rates.

ganic matter and other nutrients. Nevertheless, root growth is more affected by nitrogen and phosphorus supply than by other nutrients (Marschner, 1995). Growth decrease caused by phosphorus deficiency is generally higher in the aerial portion than in the roots (Grant et al., 2001), which explains the higher RSDMR with the lowest rates of magnesium thermophosphate. On the other hand, nitrogen supply increases both aerial and root growth, but the effect is usually greater in the aerial portion, which decreased RSDMR (Marschner, 1995). This did not occur when this evaluation was made, and is difficult explain why the nutrient supply from bovine manure did not provide the necessary effect in the aerial portion in order to reduce this relation.

\section{Relative growth rate in stem height and relative growth rate in stem diameter}

RGRSH and RGRSD varied only in function of bovine manure rates, fitting quadratic growth (Figure 9) and linear growth (Figure 10) models, respectively.

A relatively large amount of carbohydrates and amino acids is required to promote the continuous growth of any meristem (Meyer et al., 1983). Therefore, nutrients provided by bovine manure and those already present in the soil might have been crucial for stem apical meristems, especially nitrogen to form amino acids. This increases RGRSH, which had a maximum value $\left(0.029 \mathrm{~cm} / \mathrm{cm} \mathrm{day}^{-1}\right)$ at the $23 \mathrm{~g} \mathrm{~kg}^{-1}$ rate.

On the other hand, is notorious that stem diameter growth results especially in lateral meristems. Hence, nitrogen deficiency can result in eggplant thin stem (Haag \& Homa, 1968). Bovine manure provided enough nitrogen for RGRSD to become $0.015 \mathrm{~cm} / \mathrm{cm}$ day $^{-1}$, with the highest applied rate $\left(28.3 \mathrm{~g} \mathrm{~kg}^{-1}\right)$. The great demand of nitrogen for secondary stem growth partially explains the absence of a response to magnesium thermophosphate, which does not contain nitro-

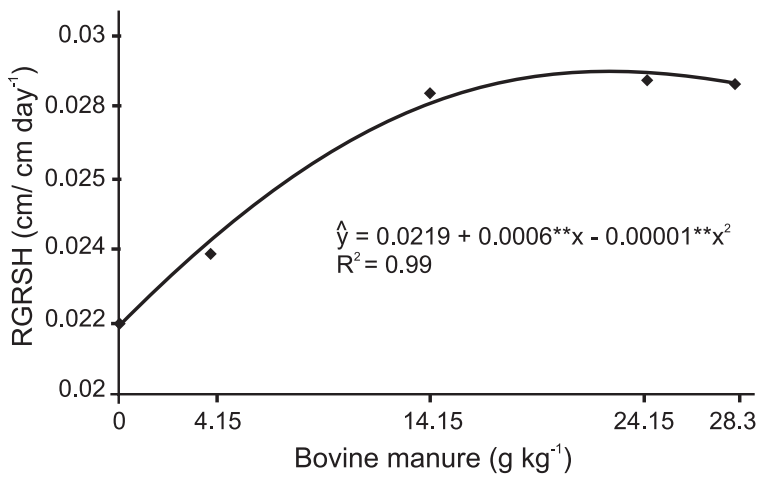

Figure 9 - Eggplant relative growth rate in stem height (RGRSH) as a function of bovine manure rates.

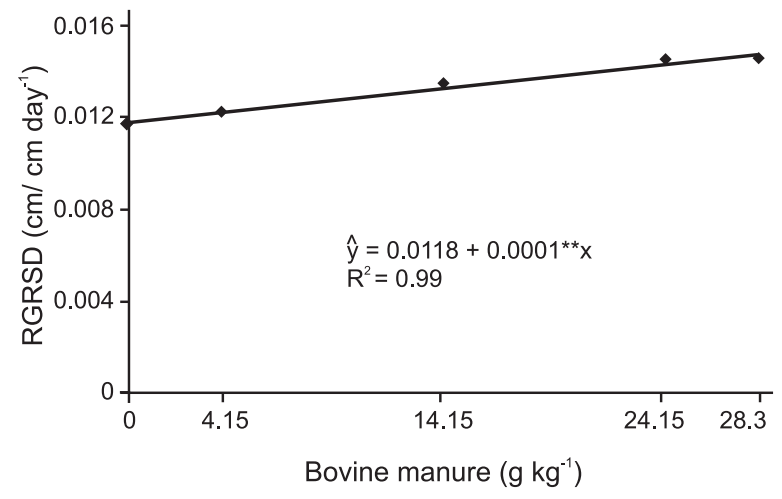

Figure 10 - Eggplant relative growth rate in stem diameter (RGTSD) as a function of bovine manure rates. 
gen. Furthermore, bovine manure improves the soil, especially its hydrophilic properties, contributing to reduce the elongation rate that can occur under low water availability (Cayon et al., 1991). This may have a positive influence on stem diameter growth.

\section{Additional treatments effect on growth parameters}

When comparing magnesium thermophosphate with and without cow urine (Table 1) higher values were found for LDMM, TDMM and RGRSH with urine, besides the fact that LDMM was determining TDMM's highest value. The LA, nevertheless, had its greatest value in the absence of cow urine, consistent with SLA's greatest absolute value. Some minor urine compounds alter nitrogen microbial transformations and also increase soil $\mathrm{NH}_{3}$ volatilization, decreasing soil $\mathrm{NH}_{4}$ concentrations (Shand et al., 2002). This may have decreased the absorbtion of nitrogen, which is important for foliar expansion. Leaf dry matter mass increment can also reduce leaf area expansion (Brighenti et al., 1993).

TDMM, SDMM, LDMM, RDMM, LA and RSDMR were higher for the conventional treatment (Table 1), with increments of $89.9 \% ; 68.6 \% ; 56.5 \%$; $196.3 \% ; 91.8 \%$ and $77.8 \%$, respectively. In absolute terms, the greatest effect of magnesium thermophosphate with cow urine was on RDMM, while the smallest on LDMM, with these results determining a RSDMR and TDMM contrast significance. The LA increment was also considerable. Nitrogen from urea may have been decisive for these results due to benefit for root growth, important for increment of nutrient absorption by root interception (Malavolta, 1980). On the other hand, the answer to phosphorus and potassium application is greater with high nitrogen availability (Mengel \& Kirkby, 1987).

\section{Principal component analysis}

Principal component analysis was used to summarize growth parameters, which permitted the identification of two principal components, representing $85.3 \%$ of the total variance of original parameters (Table 2). Principal component 1 (PC1) may be interpreted as a overall plant growth indicator, in which the coefficients represent multivariate contributions, and showing a balance of parameters with prominence of RDMM (0.2128), LA (0.2085), SDMM (0.2003) and RGRSH (0.1942). The PC1 increased linearly with the increase of bovine manure and magnesium thermophosphate rates (Figure 11), with the highest value appearing at the combination of the highest applied rates. However, the linear increment of bovine manure was much more evident, probably because eggplants require considerable amounts of nitrogen (Malavolta et al., 1974).
Principal component 2 (PC2) represents competition between root growth, expressed by RSDMR (0.7809) and RDMM (0.4522), and aerial growth, expressed by RGRSH (-0.5086) and RGRSD (-0.5078), since these variables present the highest coefficients, though with opposite signs. PC2 was affected by bovine manure and magnesium thermophosphate in an excrescent quadratic equation, with positive interaction (Figure 12), and had a minimum value (2.77) at the rates of $16 \mathrm{~g}$ $\mathrm{kg}^{-1}$ and $574 \mathrm{mg} \mathrm{kg}^{-1}$, respectively, which emphasized aerial growth, and its value increased up to the highest rates. The physical limits of the containers are responsible for root volume growth and delimit conditions for water and nutrient availability, salinity levels and stratum aeration (Marouelli et al., 2005). Even with physical impediments in the environment, roots kept growing, probably because of root improvement in physical and chemical terms through

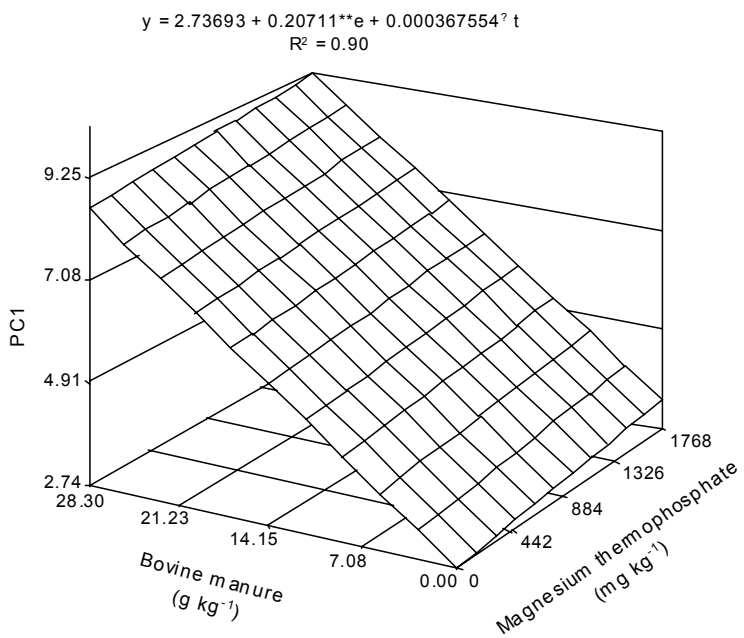

Figure 11 - Principal component 1 (PC1) of eggplant growth parameters, as a function of bovine manure and magnesium thermophosphate rates.

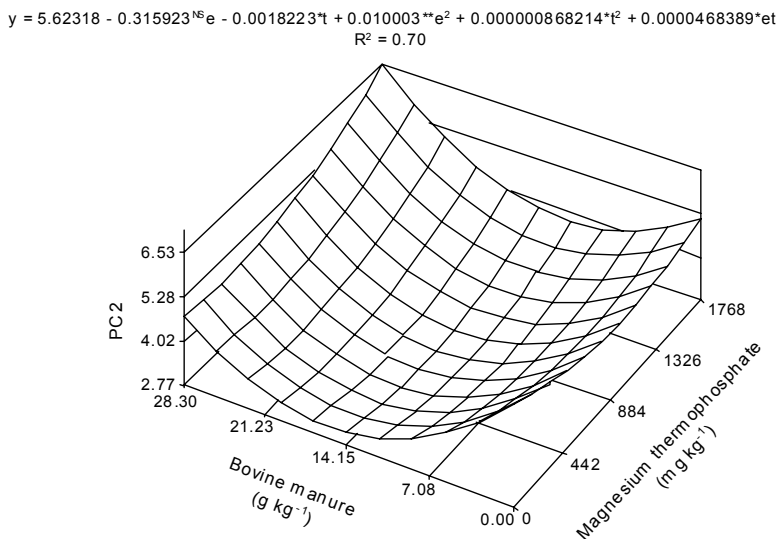

Figure 12 - Principal component 2 (PC2) of competition between eggplant root system and shoot as a function of bovine manure and magnesium thermophosphate rates. 
Table 1 - Treatment averages and estimatives ( $\hat{Y}$ ) of the contrasts of magnesium thermophosphate without cow urine (MT without $\mathrm{CU}$ ) versus magnesium thermophosphate with cow urine (MT with $\mathrm{CU}$ ), and triple superphosphate with urea (TS with Ur) versus MT with CU for growth characteristic in eggplant.

\begin{tabular}{|c|c|c|c|c|c|}
\hline \multirow[b]{2}{*}{ Parameter } & \multicolumn{3}{|c|}{ Averages } & \multicolumn{2}{|c|}{$\hat{\mathrm{Y}}$} \\
\hline & MT with $\mathrm{CU}$ & $\begin{array}{c}\text { MT without } \\
\text { CU }\end{array}$ & TS with Ur & $\begin{array}{l}\text { MT without } \mathrm{CU} \\
\text { vs } \mathrm{MT} \text { with } \mathrm{CU}\end{array}$ & $\begin{array}{l}\text { TS with Ur } v s \\
\text { MT with CU }\end{array}$ \\
\hline Total $\mathrm{DMM}^{1}$ (g per plant) & 38.91 & 33.29 & 73.25 & $-562 *$ & $34.34 * *$ \\
\hline Shoot DMM (g per plant) & 32.91 & 27.66 & 55.48 & $-5.25 n s$ & $22.57 * *$ \\
\hline Leaf DMM (g per plant) & 16.71 & 12.88 & 26.15 & $-3.83 * *$ & $9.44 * *$ \\
\hline Root DMM (g per plant) & 6.00 & 5.63 & 17.78 & $-0.37^{\mathrm{ns}}$ & $11.78 * *$ \\
\hline Leaf area $\left(\mathrm{cm}^{2}\right)$ & 3584.25 & 4542.16 & 6874.50 & $957.91 * *$ & $3290.25 * *$ \\
\hline Specific leaf area $\left(\mathrm{cm}^{2} \mathrm{~g}^{-1}\right)$ & 272.14 & 279.64 & 262.50 & $7.50^{\mathrm{ns}}$ & $-9.64^{\mathrm{ns}}$ \\
\hline Leaf area ratio $\left(\mathrm{cm}^{2} \mathrm{~g}^{-1}\right)$ & 138.01 & 129.63 & 124.34 & -8.41 & $-13.70^{\mathrm{ns}}$ \\
\hline Root shoot DM ratio $\left(\mathrm{g} \mathrm{g}^{-1}\right)$ & 0.18 & 0.21 & 0.32 & 0.03 & $0.14 * *$ \\
\hline RGRSH $\left(\mathrm{cm} / \mathrm{cm} \mathrm{day}^{-1}\right)$ & 0.0293 & 0.0272 & 0.0285 & $-0.0021 * *$ & $-0.0008^{\mathrm{ns}}$ \\
\hline $\operatorname{RGRSD}\left(\mathrm{cm} / \mathrm{cm}\right.$ day $\left.^{-1}\right)$ & 0.0149 & 0.0136 & 0.0143 & $-0.013^{\mathrm{ns}}$ & $-0.0006^{\mathrm{ns}}$ \\
\hline
\end{tabular}

${ }^{* *, *}$ Significant at $1 \%$ and $5 \%$ of probability, respectively, and ${ }^{\mathrm{ns}}$ non-significant, by $\mathrm{F}$ test; values of F corrected by Bonferroni's test, for non-orthogonality contrasts. ${ }^{1} \mathrm{DM}$ (dry matter); DMM (dry matter mass); RGRSH (relative growth rate in stem height); RGRSD (relative growth rate in stem diameter).

Table 2 - Eggplant eigenvectors in two principal components (PC1 and PC2) of shoot dry matter mass (SDMM), root dry matter mass (RDMM), leaf area (LA), root shoot dry matter ratio (RSDMR), relative growth rate in stem height (RGRSH) and relative growth rate in stem diameter (RGRSD).

\begin{tabular}{lcc}
\hline Parameter & PC1 & PC2 \\
\hline SDMM & $\mathbf{0 . 2 0 0 3}$ & 0.0433 \\
RDMM & $\mathbf{0 . 2 1 2 8}$ & $\mathbf{0 . 4 5 2 2}$ \\
LA & $\mathbf{0 . 2 0 8 5}$ & -0.3049 \\
RSDMR & 0.1809 & $\mathbf{0 . 7 8 0 9}$ \\
RGRSH & $\mathbf{0 . 1 9 4 2}$ & $\mathbf{- 0 . 5 0 8 6}$ \\
RGRSD & 0.1650 & $\mathbf{- 0 . 5 0 7 8}$ \\
\hline$\lambda$ & 4.41 & 0.70 \\
AV $(\%)$ & 73.59 & 85.28 \\
\hline
\end{tabular}

$\lambda=$ Correlation matrix autovalue; $\mathrm{AV}=\mathrm{Accumulated}$ variance.

increased manure rates, resulting in less growth stress. For the smallest rates of both inputs, although there was competition, the root increment was less intense and it can be ascribed to insufficient nutrients to support balanced growth. Nutrients were shifted to root growth in detriment of RGRSH and RGRSD. This happens because growth reduction due to phosphorus deficiency is generally higher in the aerial part than in the roots (Grant et al., 2001), and nitrogen supply has a greater effect in the aerial part (Marschner, 1995). Therefore, this is the part which will probably be affected first if nutrient supply is insufficient.
Table 3 - Canonic correlations between eggplant growth parameters with chemical substrate attributes.

\begin{tabular}{lc}
\hline Parameter and attributes & Canonic Pair \\
\hline Growth parameter & \\
\hline Shoot dry matter mass (SDMM) & $\mathbf{0 . 2 9 6 1}$ \\
Roots dry matter mass (RDMM) & $\mathbf{0 . 4 3 0 6}$ \\
\hline Leaf area (LA) & 0.1134 \\
\hline Substrate attribute & \\
Organic matter & -0.1126 \\
Phosphorus & $\mathbf{0 . 3 5 6 6}$ \\
Potassium & $\mathbf{0 . 8 9 7 5}$ \\
Calcium & -0.0987 \\
Magnesium & -0.0587 \\
pH (in CaCl ${ }_{2}$ ) & -0.2038 \\
R & 0.98 \\
Significance & $* *$ \\
\hline ** Significant at $1 \%$ of probability by chi square test; R = canonic \\
correlation.
\end{tabular}

\section{Canonic correlations between growth parameters and substrate attributes}

Canonic correlations between the growth parameters SDMM, RDMM and LA and substrate attributes (Table 3 ) were significant $(P<0.01)$ only for a canonical pair, with a highly significant correlation coefficient value $(\mathrm{R}=0.98)$. The canonic coefficient (cc) represents the joint variable contribution to the function, which is linear, that is, it represents the cc influence in the presence of other variables (Rencher, 1992). This canonic pair demonstrates that RDMM $(\mathrm{cc}=0.4306)$ and SDMM $(\mathrm{cc}=0.2961)$ were higher 
with greater potassium $(\mathrm{cc}=0.8975)$ and phosphorus $(0.3566)$ availability in the substrate. The fact that no correlation with soil organic matter content was observed, even with applied bovine manure, leads to presume that the soil nitrogen content did not have relation to it, considering the importance of this nutrient on these growth parameters. This can be attributed to the complex nitrogen dynamics in the soil which is also influenced by other factors (Raij, 1991).

\section{CONCLUSIONS}

More growth parameters were positively affected by bovine manure than by magnesium thermophosphate. The overall plant growth (Principal component 1), which summarizes all parameters, was linearly incremented 564 times more by bovine manure than by magnesium thermophosphate, thus confirming greatly these results. Therefore, these results denote good expectations for the organic production of eggplant, in case of confirmation of this performance under field conditions. The potential of cow urine used as an alternative nutrient source was not confirmed. Although it increased some growth parameters, it interfered negatively on leaf area, and all results were inferior to those obtained with urea. Canonic correlations emphasized that RDMM and SDMM were higher with a greater potassium and phosphorus availability in the substrate. However, an association with soil organic matter did not occur, which was attributed to the absence of a direct relation with soil nitrogen, since the dynamic of this nutrient is influenced by other factors.

\section{REFERENCES}

ABREU, I.N.; PINTO, J.E.B.P.; FURTINI NETO, A.E.; BERTOLUCCI, S.K.V.; LADEIRA, A.; GEROMEL, C. Nitrogênio e fósforo na produção vegetal e na indução de mucilagem em plantas de insulina. Horticultura Brasileira, v.20, p.536-540, 2002.

ALVAREZ V, V.H. Avaliação da fertilidade do solo: superfície de resposta: modelos aproximativos para expressas a relação fator-resposta. Viçosa: UFV, 1991. 75p.

BAYER, C.; MIELNICZUK, J. Dinâmica e função da matéria orgânica. In: SANTOS, G.A.; CAMARGO, F.A.O. (Ed.) Fundamentos da matéria orgânica. Porto Alegre: Gênesis, 1999. p.9-26.

BENINCASA, M.M.P. Análise de crescimento de plantas. Jaboticabal: FUNEP, 1988. 42p.

BODDEY, R.M.; ALVES, B.J.R.; OLIVEIRA, O.C. A degradação das pastagens e o ciclo do nitrogênio. In: WORKSHOP NITROGÊNIO NA SUSTENTABILIDADE DE SISTEMAS INTENSIVOS DE PRODUÇÃo AGROPECUÁRIA, Dourados, 2000. Anais. Dourados: Embrapa Agropecuária Oeste, 2000. p.110-124.

BortoluzZI, A.L.; ALVAREZ V., V.H. Pesquisa em casa de vegetação e em campo: matrizes experimentais. Viçosa: UFV, 1997. 73p.

BRIGHENTI, A.M.; SILVA, J.F.; LOPES, N.F.; CARDOSO, A.A.; FERREIRA, L.R. Crescimento e partição de assimilados em Losna. Revista Brasileira de Fisiologia Vegetal, v.5, p.41-45, 1993.
CARADUS, J.R.; DUNLOP, J.; WEWALA, S.; MacKAY, A.D.; HART, A.L.; BOSCH, J. van den; HAY, M.J.M.; LAMBERT, M.G. Nitrogen and phosphorus concentrations of white clover genotypes differing in response to added phosphorus. New Zealand Journal of Agricultural Research, v.36, p.79-86, 1993.

CARDOSO, M.O. Índices fisiológicos e de produção de berinjela com uso de matéria orgânica e termofosfato magnesiano. Areia: UFPB/CCA, 2005. 187p. Tese (Doutorado).

CAYON, D.G.; LOPES, N.F.; CANO, M.A.O.; SAT'ANNA, R. Tolerância e crescimento de soja (Glycine $\max (\mathrm{L}$.) Merrill) tratada com imazaquin em diferentes regimes hídricos. Revista Brasileira de Fisiologia Vegetal, v.31, p.17-25, 1991.

FAO. Codex Alimentarius Comission. Guidelines for the production, processing, labeling and marketing of organically produced foods. Rome: FAO/WHO, 1999. 43p.

FERREIRA, M.E.; CRUZ, M.C.P.; FERREIRA JUNIOR, M.E. Avaliação da fertilidade empregando o sistema IAC de análise de solo. Jaboticabal: UNESP/FCAV, 1990. 94p.

FERREIRA, M.M.M.; FERREIRA, G.B.; FONTES, P.C.R.; DANTAS, J.P. Produção de tomateiro em função de doses de nitrogênio e da adubação orgânica em duas épocas de cultivo. Horticultura Brasileira, v.21, p.468-473, 2003.

FILGUEIRA, F.A.R. Solanáceas: agrotecnologia moderna na produção de tomate, batata, pimentão, pimenta, berinjela e jiló. Lavras: IFLA, 2003. 333p.

FONTES, P.C.R.; DIAS, E.N.; SILVA, D.J.H. Dinâmica de crescimento, distribuição de matéria seca e produção de pimentão em ambiente protegido. Horticultura Brasileira, v.23, p.9499, 2005.

FONTES, P.C.R.; WILCOX, G.E. Growth and phosphorus uptake by tomato cultivars as influenced by phosphorus concentrations in soil and nutrient solution. Journal of the American Society for Horticultural Science, v.109, p.633-636, 1984.

GADELHA, R.S.S. Urina de vaca na produção de alimentos. Agroecologia, v.2, p.25-26, 2001.

GILL, J.L. Uses and abuses of statistical methods in research in parasitology. Veterinary Parasitology, v.36, p.189-209, 1990.

GOMES, F.P. A estatística moderna na pesquisa agropecuária. Piracicaba: Potafos, 1985. 160p.

GRANT, C.A.; FLATEN, D.N.; TOMASIEWICZ, D.J.; SHEPPARD, S.C. A importância do fósforo no desenvolvimento inicial da planta. Piracicaba: Potafos, 2001. 5p. (Informações Agronômicas, 95).

HAAG, H.P.; HOMA, P. Nutrição mineral de hortaliças: deficiências de macronutrientes em berinjela. Anais da Escola Superior de Agricultura "Luiz de Queiroz", v.25, p.149-159, 1968.

HALLMARK, W.B.; BARBER, S.A. Root growth and morphology, nutrient uptake, and nutrient status of early growth of soybeans as affected by soil P and K. Agronomy Journal, v.76, p.209212, 1984.

HUNT, R. Basic growth analysis. London: Unwin Hyman, 1990. $112 \mathrm{p}$.

JACKSON, J.E. A user's guide to principal components. New York: John Wiley, 1991. 569p.

KIEHL, E.J. Fertilizantes orgânicos. Piracicaba: Ceres, 1985. 492p.

MALAVOLTA, E. Elementos de nutrição mineral de plantas. São Paulo: Ceres, 1980. 251p.

MALAVOLTA, E.; HAAG, H.P.; MELLO, F.A.F.; BRASIL SOBRINHO, M.O.C. Nutrição mineral e adubação de plantas cultivadas. São Paulo: Pioneira, 1974. 752p.

MAPELI, N.C.; VIEIRA, M.C.; HEREDIA Z, N.A.; SIQUEIRA, J.M. Produção de biomassa e de óleo essencial dos capítulos florais da camomila em função de nitrogênio e fósforo. Horticultura Brasileira, v.23, p.32-37, 2005.

MAROUELLI, W.A.; CARRIJO, O.A.; ZOLNIER, S. Variabilidade espacial do sistema radicular do tomateiro e implicações no manejo da irrigação em cultivo sem solo com substratos. Horticultura Brasileira, v.23, p.57-60, 2005. 
MARSCHNER, H. Mineral nutrition of higher plants. 2. ed. London: Academic Press, 1995. 889p.

MENDONÇA, E.S; LOURES, E.G. Matéria orgânica do solo. Brasília: ABEAS, 1995. 45p. (ABEAS. Curso de Fertilidade e Manejo de Solo, Módulo 5).

MENGEL, K.; KIRKBY, E.A. Principles of plant nutrition. 4. ed. Bern: International Potash Institute, 1987. 687p.

MEYER, B.; ANDERSON, D.; BOHNING, R.; FRATIANE, D. Introdução à fisiologia vegetal. 2. ed. Lisboa: Calouste Gulbenkian, 1983. 710p.

PEREIRA, A.R.; MACHADO, E.C. Análise quantitativa do crescimento de comunidades vegetais. Campinas: Instituto Agronômico, 1987. 33p. (Boletim Técnico, 114).

RAIJ, B. van. Fertilidade do solo e adubação. Piracicaba: Ceres/ Potafos, 1991. 343 p.

RENCHER, A.C. Interpretation of canonical discriminant functions, canonical variates and principal components. The American Statistician, v.46, p.217-225, 1992.

RIBEIRO, C.S.C.; BRUNE, S.; REIFCHNEIDER, F.J.B. Cultivo da berinjela. Brasília: Embrapa Hortaliças, 1998. 23p. (Instrução Técnica, 15).

RIBEIRO JÚNIOR, J.I. Análises estatísticas no SAEG. Viçosa: UFV, 2001, 301p.

RODRIGUES, C.R.; FAQUIN, V.; TREVISAN, D.; PINTO, J.E.B.P.; BERTOLUCCI, S.K.V.; RODRIGUES, T.M. Nutrição mineral, crescimento e teor de óleo essencial da menta em solução nutritiva sob diferentes concentrações de fósforo e épocas de coleta. Horticultura Brasileira, v.22, p.573-578, 2004.
RONCHI, C.P.; FONTES, P.C.R.; PEREIRA, P.R.G.; NUNES, J.C.S.; MARTINEZ, H.E.P. Índices de nitrogênio e de crescimento do tomateiro em solo e em solução nutritiva. Revista Ceres, v.48, p.469-484, 2001.

SCOTT, H.D.; BATCHELOR, J.T. Dry weight and leaf area production rates of irrigated determinate soybeans. Agronomy Journal, v.71, p.776-782, 1979.

SHAND, C.A.; WILLIAMS, B.L.; DAWSON, L.A.; SMITH, S.; YOUNG, M.E. Sheep urine affects soil solution nutrient composition and roots: differences between field and sward box soils and the effects of synthetic and natural sheep urine. Soil Biology \& Biochemistry, v.34, p.163-171, 2002.

SILVA, N.F.; FERREIRA, F.A.; FONTES, P.C.R.; SEDIYAMA, M.A. N. Crescimento e estado nutricional de abóbora híbrida em função de adubação orgânica e mineral. Horticultura Brasileira, v.17, p.193-200, 1999.

SWIADER, J.M.; MORSE, R.D. Phosphorus solution concentrations for production of tomato, pepper and eggplant in Minesoils. Journal of the American Society for Horticultural Science, v.107, p.1149-1153, 1982.

TAIZ, L.; ZEIGER, E. Fisiologia vegetal. 3. ed. Porto Alegre: Artmed, 2004. 719p.

YAMADA, T. Melhoria na eficiência da adubação aproveitando as interações entre os nutrientes. Piracicaba: Potafos, 2002. 5p. (Informações Agronômicas, 100).

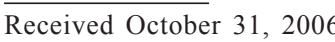

Accepted August 02, 2007 